\title{
Pengaruh Kecerdasan Emosional, Kecerdasan Spiritual dan Perilaku Belajar Terhadap Pemahaman Akuntansi
}

\author{
FAHMI OEMAR $^{1}$; FACHRI DWIFA OKTO FANI ${ }^{2}$ \\ ${ }^{1,2}$ Universitas Lancang Kuning \\ Jln. Yos Sudarso KM 08 Rumbai Telp. (0761) 52581 \\ E-mail : fachri.dwifa@gmail.com
}

\begin{abstract}
This study aims to find out, analyze, and obtain empirical evidence about the effect of the influence of emotional intelligence, spiritual intelligence and learning behavior on understanding accounting. (case study for students majoring in 2012-2013 force accounting at a presumptuous university). This research was conducted using a survey method with a questionnaire. In this study covers 232 respondents from 320 students majoring in accounting for 2012-2013. The data analysis method used is multiple linear regression analysis, the type of data used in this study is qualitative data. Test results of statistical data analysis simultaneously shows that the significance value is 0,000 which is smaller than alpha 0.05 . This shows that emotional intelligence, spiritual intelligence and learning behavior simultaneously have a significant effect on understanding accounting. The results of statistical tests partially show that emotional intelligence, spiritual intelligence, and learning behavior affect accounting understanding.
\end{abstract}

Keywords: Effect of Emotional Intelligence, Spiritual Intelligence, and Learning Behavior on Accounting Understanding

Pada dasarnya pendidikan merupakan suatu usaha yang dilakukan oleh manusia untuk meningkatkan taraf hidup ke arah yang lebih sempurna. Pendidikan juga merupakan suatu kekuatan yang dinamis yang sangat berpengaruh/integritas kekuatan yang saling berpengaruh (implikasi) dalam berbagai hal seperti terhadap perkembangan emosi, fisik, mental, etika/perilaku, kepercayaan akan kemampuan personal dan seluruh aspek perkembangan manusia lainnya serta salah satu faktor yang besar peranannya bagi kehidupan bangsa karena dapat mendorong dan menentukan maju mundurnya bangsa dalam segala bidang.(Hanifah dan Syukriy Abdullah (2001) dalam Septian Hariyoga Edy Suprianto 2011).

Proses belajar di perguruan tinggi merupakan proses yang sifatnya kompleks dan menyeluruh. Banyak orang yang berpendapat bahwa untuk meraih prestasi yang tinggi dalam belajar, seorang mahasiswa harus memiliki Intelligence Quotient (IQ) yang tinggi, karena inteligensi merupakan bekal potensial yang akan memudahkan dalam belajar dan pada gilirannya akan menghasilkan prestasi belajar yang optimal.

Kecerdasan emosional mahasiswa memiliki pengaruh terhadap prestasi belajar mahasiswa. Kecerdasan emosional ini mampu melatih kemampuan untuk mengelola perasaannya, kemampuan untuk memotivasi dirinya, kesanggupan untuk tegar dalam menghadapi frustasi, kesanggupan mengendalikan dorongan dan menunda kepuasan sesaat, mengatur suasana hati yang reaktif, serta mampu berempati dan bekerja sama dengan orang lain. Kecerdasan ini yang mendukung seorang mahasiswa dalam mencapai tujuan dan cita-citanya. Kemampuan untuk mengembangkan kepribadian mahasiswa pada masa sekarang ini lebih dikenal dengan istilah Emotional Quotient (EQ) atau kecerdasan emosional.

Menurut Zohar dan Marshall (2001) mendefinisikan kecerdasan spiritual sebagai kemampuan internal bawaan otak dan jiwa manusia yang sumber terdalamnya adalah inti alam 
semesta sendiri, yang memungkinkan otak untuk menemukan dan menggunakan makna dalam memecahkan persoalan. Tolak ukur ini tidak salah tetapi tidak seratus persen bisa dibenarkan. Terdapat faktor lain yang menyebabkan seseorang menjadi sukses yaitu adanya kecerdasan emosional dan kecerdasan spiritual. (Filia Rachmi ,2010).

Perilaku belajar mahasiswa saat di perguruan tinggi mempengaruhi tingkat pemahaman akuntansi. Namun, di Indonesia proses belajar yang sedang berjalan pada umumnya belum bisa dipandang sebagai proses belajar mandiri (Suwardjono, 2004:7).

Belajar adalah proses perubahan perilaku akibat interaksi individu dengan lingkungan. Belajar adalah suatu proses usaha yang kompleks dilakukan seseorang dari tidak tahu menjadi tahu, tidak mengerti menjadi mengerti, dan sebagainya untuk memperoleh perubahan tingkah laku yang lebih baik secara keseluruhan akibat interaksinya dengan lingkungannya. (Masyitah As Sahara,2014).

Tingkat pemahaman akuntansi menjadi sangat penting. Melalui tingkat pemahaman akuntansi dapat diketahui seberapa cukupkah ilmu akuntansi yang sudah dimiliki seorang akuntan agar bisa melaksanakan peran profesi akuntan di dunia bisnis. Tingkat pemahaman akuntansi mahasiswa dinyatakan dengan seberapa mengerti seorang mahasiswa terhadap apa yang sudah dipelajari dalam konteks ini mengacu pada mata kuliah akuntansi. Tanda seorang mahasiswa memahami akuntansi tidak hanya ditunjukkan dari nilai-nilai yang didapatkannya dalam mata kuliah tetapi juga apabila mahasiswa tersebut mengerti dan dapat menguasai konsepkonsep yang terkait. Oleh karena itu pendidikan tinggi akuntansi bertanggung jawab mengembangkan keterampilan mahasiswanya untuk tidak hanya memiliki kemampuan lain yang diperlukan untuk berkarir di lingkungan yang selalu berubah dan ketat persaingannya.
Kecerdasan emosional merupakan dasar untuk mengembangkan kecakapan emosi yang dipelajari berdasarkan kecerdasan emosi tersebut. Kecerdasan emosional menunjang potensi individu guna mengkaji ketrampilan-ketrampilan praktis dengan berdasar pada lima unsur, sedangkan kecakapan emosi mencerminkan banyaknya potensi yang dimiliki oleh individu dan diterapkan pada kehidupan sehari-hari.

Trisniwati dan Suryaningsum (2003) dalam Prenichawati ishak (2010) yang mendefinisikan bawa "Kecerdasan emosional adalah kemampuan merasakan, memahami, dan secara selektif menerapkan daya dan kepekaan emosi sebagai sumber energi dan pengaruh yang manusiawi".

Goleman (2005:245) membagi kecerdasan emosional menjadi lima bagian yaitu tiga komponen berupa kompetensi emosional (pengenalan diri, pengendalian diri dan motivasi) dan dua komponen berupa kompetensi sosial (empati dan keterampilan sosial). Lima komponen kecerdasan emosional tersebut adalah sebagai berikut: 1) Pengenalan diri. Pengenalan diri adalah kemampuan seseorang untuk mengetahui perasaan dalam dirinya dan digunakan untuk membuat keputusan bagi diri sendiri, memiliki tolak ukur yang realistis atas kemampuan diri dan memiliki kepercayaan diri yang kuat. Unsur-unsur kesadaran diri, yaitu: Kesadaran emosi (emosional awareness), yaitu mengenali emosinya sendiri dan efeknya; Penilaian diri secara teliti (accurate self awareness), yaitu mengetahui kekuatan dan batasbatas diri sendiri; Percaya diri (self confidence), yaitu keyakinan tentang harga diri dan kemampuan sendiri. 2) Pengendalian Diri. Pengendalian diri adalah kemampuan menangani emosi diri sehingga berdampak positif pada pelaksanaan tugas, peka terhadap kata hati, sanggup menunda kenikmatan sebelum tercapainya suatu sasaran, dan mampu segera pulih dari tekanan emosi. 
Unsur-unsur pengendalian diri, yaitu: Kendali diri (self-control), yaitu mengelola emosi dan desakan hati yang merusak; Sifat dapat dipercaya (trustworthiness), yaitu memelihara norma kejujuran dan integritas; Kehati-hatian (conscientiousness), yaitu bertanggung jawab atas kinerja pribadi; Adaptabilitas (adaptability), yaitu keluwesan dalam menghadapi perubahan; Inovasi (innovation), yaitu mudah menerima dan terbuka terhadap gagasan, pendekatan, dan informasi-informasi baru. 3) Motivasi. Motivasi adalah kemampuan menggunakan hasrat agar setiap saat dapat membangkitkan semangat dan tenaga untuk mencapai keadaan yang lebih baik, serta mampu mengambil inisiatif dan bertindak secara efektif. Unsur-unsur motivasi, yaitu: Dorongan prestasi (achievement drive), yaitu dorongan untuk menjadi lebih baik atau memenuhi standar keberhasilan; Komitmen (commitmen), yaitu menyesuaikan diri dengan sasaran kelompok atau lembaga; Inisiatif (initiative), yaitu kesiapan untuk memanfaatkan kesempatan; Optimisme (optimisme), yaitu kegigihan dalam memperjuangkan sasaran kendati ada halangan dan kegagalan. 4) Empati. Empati adalah kemampuan merasakan apa yang dirasakan oleh orang lain. Mampu memahami perspektif orang lain dan menimbulkan hubungan saling percaya, serta mampu menyelaraskan diri dengan berbagai tipe individu. Unsur-unsur empati, yaitu: Memahami orang lain (understanding others), yaitu mengindra perasaan dan perspektif orang lain dan menunjukkan minat aktif terhadap kepentingan mereka; Mengembangkan orang lain (developing other), yaitu merasakan kebutuhan perkembangan orang lain dan berusaha menumbuhkan kemampuan orang lain; Orientasi pelayanan (service orientation), yaitu mengantisipasi, mengenali, dan berusaha memenuhi kebutuhan pelanggan; Memanfaatkan keragaman (leveraging diversity), yaitu menumbuhkan peluang melalui pergaulan dengan bermacammacam orang; Kesadaran politis (political awareness), yaitu mampu membaca arusarus emisi sebuah kelompok dan hubungannya dengan perasaan. 5) Keterampilan. Ketrampilan sosial adalah kemampuan menangani emosi dengan baik ketika berhubungan dengan orang lain, bisa mempengaruhi, memimpin, bermusyawarah, menyelasaikan perselisihan, dan bekerjasama dalam tim. Unsur-unsur ketrampilan sosial, yaitu: Pengaruh (influence), yaitu memiliki taktik untuk melakukan persuasi; Komunikasi (communication), yaitu mengirim pesan yang jelas dan meyakinkan; Manajemen konflik (conflict management), yaitu negoisasi dan pemecahan silang pendapat; Kepemimpinan (leadership), yaitu membangitkan inspirasi dan memandu kelompok dan orang lain; Katalisator perubahan (change catalyst), yaitu memulai dan mengelola perusahaan; Membangun hubungan (building bond), yaitu menumbuhkan hubungan yang bermanfaat; Kolaborasi dan kooperasi (collaboration and cooperation), yaitu kerjasama dengan orang lain demi tujuan bersama; Kemampuan tim (tim capabilities), yaitu menciptakan sinergi kelompok dalam memperjuangkan tujuan bersama.

Zohar dan Marshall (2007:115) mendefinisikan kecerdasan spiritual sebagai "Kemampuan internal bawaan otak dan jiwa manusia yang sumber terdalamnya adalah inti alam semesta sendiri, yang memungkinkan otak untuk menemukan dan menggunakan makna dalam memecahkan persoalan".

Agustian

(2004:137)

mendefinisikan kecerdasan spiritual sebagai "Kemampuan untuk meberi makna ibadah terhadap setiap perilaku dan kegiatan melalui langkah-langkah dan pemikiran yang bersifat fitrah, menuju manusia yang seutuhnya dan memiliki pola pemikiran integralistik, serta berprinsip hanya karena Allah".

Kecerdasan spiritual ini dalam pandangan khalayak meliputi 
kemampuan dalam menelaah nilai dan makna-makna, kesadaran diri, fleksibilitas dan adaptatif. Spiritualitas bukan berarti selalu dikorelasikan dengan kedekatan seseorang dengan aspek ketuhanan, sebab seorang humanis ataupun atheis pun dapat memiliki spiritualitas tinggi (Armansyah, 2002:23-22).

Zohar dan Marshall (2007), kecerdasan spiritual adalah kecerdasan untuk menghadapi dan memecahkan persoalan makna dan nilai, yaitu kecerdasan untuk menempatkan perilaku dan hidup manusia dalam konteks makna yang lebih luas dan kaya, untuk menilai bahwa tindakan atau jalan hidup seseorang lebih bermakna dibandingkan yang lain.

Ciri-ciri orang yang memiliki kecerdasan spiritual berdasarkan teori Zohar dan Marshall (2001) dan Sinetar (2001) dalam Bowo (2009), yaitu: a. Memiliki Kesadaran Diri. Memiliki kesadaran diri yaitu adanya tingkat kesadaran yang tinggi dan mendalam sehingga bisa menyadari berbagai situasi yang datang dan menanggapinya. b. Memiliki Visi. Memiliki visi yaitu memiliki pemahaman tentang tujuan hidup dan memiliki kualitas hidup yang diilhami oleh visi dan nilai-nilai. c. Bersikap Fleksibel. Bersikap fleksibel yaitu mampu menyesuaikan diri secara spontan dan aktif untuk mencapai hasil yang baik, memiliki pandangan yang pragmatis (sesuai kegunaan), dan efisien tentang realitas. d. Berpandangan Holistik. Berpandangan holistik yaitu melihat bahwa diri sendiri dan orang lain saling terkait dan bisa melihat keterkaitan antara berbagai hal. Dapat memandang kehidupan yang lebih besar sehingga mampu menghadapi dan memanfaatkan, melampaui kesengsaraan dan rasa sehat, serta memandangnya sebagai suatu visi dan mencari makna dibaliknya. e. Melakukan Perubahan. Melakukan perubahan yaitu terbuka terhadap perbedaan, memiliki kemudahan untuk bekerja melawan konvensi dan status quo dan juga menjadi orang yang bebas merdeka. f. Sumber Inspirasi. Sumber inspirasi yaitu mampu menjadi sumber inspirasi bagi orang lain dan memiliki gagasan-gagasan yang segar. g. Refleksi Diri. Refleksi diri yaitu memiliki kecenderungan apakah yang mendasar dan pokok.

Suwardjono (2004) menyatakan bahwa belajar di perguruan tinggi merupakan suatu pilihan srategik dalam mencapai tujuan individual seseorang. Semangat, cara belajar, dan sikap mahasiswa terhadap belajar sangat dipengaruhi oleh kesadaran akan adanya tujuan individual dan tujuan lembaga pendidikan yang jelas.

Hanifah dan Syukriy (2001) dalam filia rachmi (2008) yang menguji tentang perilaku belajar terhadap tingkat prestasi akademik mahasiswa akuntansi. Perilaku belajardiukur dengan kebiasaan mengikuti pelajaran, kebiasaan membaca buku teks, kunjungan ke perpustakaan dan kebiasaan menghadapi ujian.

Dari berbagai definisi bahwa belajar merupakan proses yang dilakukan seseorang dari tidak tahu menjadi tahu, dari tidak mengerti menjadi mengerti, dan sebagainya, untuk memperoleh tingkah laku yang lebih baik secara keseluruhan akibat interaksinya dengan lingkungannya.

Menurut Suwardjono (2004) perilaku belajar yang baik terdiri dari: 1 . Kebiasaan Mengikuti Pelajaran. Kebiasaan mengikuti pelajaran adalah kebiasaan yang dilakukan mahasiswa pada saat pelajaran sedang berlangsung. Mahasiswa yang mengikuti pelajaran dengan tertib dan penuh perhatian serta dicatat dengan baik akan memperoleh pengetahuan lebih banyak. Kebiasaan mengikuti pelajaran ini ditekankan pada kebiasaan memperhatikan penjelasan dosen, membuat catatan, dan keaktifan di kelas. 2. Kebiasaan Membaca Buku. Kebiasaan membaca buku merupakan merupakan ketrampilan membaca yang paling penting untuk dikuasai mahasiswa. Kebiasaan membaca harus di budidayakan agar pengetahuan mahasiswa dapat 
bertambah dan dapat meningkatkan pemahaman mahasiswa dalam mempelajari suatu pelajaran. 3. Kunjungan ke Perpustakaan. Kunjungan ke perpustakaan merupakan kebiasaan mahasiswa mengunjungi perpustakaan untuk mencari referensi yang dibutuhkan agar dapat menambah wawasan dan pemahman terhadap pelajaran. Walaupun pada dasarnya sumber bacaan bisa ditemukan dimana-mana, namun tempat yang paling umum dan memiliki sumber yang lengkap adalah perpustakaan. 4. Kebiasaan Menghadapi Ujian. Kebiasaan menghadapi ujian merupakan persiapan yang biasa dilakukan mahasiswa ketika akan menghadapi ujian. Setiap ujian tentu dapat dilewati oleh seorang siswa dengan berhasil jika sejak awal mengikuti pelajaran, siswa tersebut mempersiapkan dengan sebaikbaiknya. Oleh karena itu, siswa harus menyiapkan diri dengan belajar secara teratur, penuh disiplin, dan konsentrasi pada masa yang cukup jauh sebelum ujian dimulai.

Menurut Budhiyanto dan paskah (2004), tingkat pemahaman akuntansi merupakan "Seberapa mengerti seorang mahasiswa terhadap apa yang sudah dipelajari yang dalam konteks ini mengacu pada mata kuliah-mata kuliah akuntansi". Tanda seorang mahasiswa memahami akuntansi tidak hanya ditunjukkan dari nilai-nilai yang di dapatkannya dalam mata kuliah, tetapi juga apabila mahasiswa tersebut mengerti dan dapat menguasai konsep-konsep yang terkait. Mahasiswa dapat dikatakan menguasai atau memahami akuntansi apabila ilmu akuntansi yang sudah diperolehnya selama ini dapat diterapkan dalam kehidupannya bermasyarakat atau dengan kata lain dapat dipraktekkan didunia kerja. Pendidikan akuntansi setidaknya harus dapat mempersiapkan peserta didik untuk memulai dan mengembangkan keaneragaman karir profesional dalam bidang Akuntansi.

Tidak ada definisi autoritatif yang cukup umum untuk dapat menjelaskan apa sebenarnya akuntansi itu, sehingga banyak definisi yang diajukan oleh para ahli dan buku teks tentang pengertian akuntansi. Akuntansi secara operasional oleh Suwardjono (2004), didefinisikan dari dua sudut pengertian yaitu sebagai disiplin/bidang pengetahuan (studi) yang diajarkan di institusi pendidikan dan sebagai kegiatan/proses yang dilakukan di dalam praktik. Dari sudut bidang studi, akun-tansi dapat didefinisikan sebagai seperangkat pengetahuan yang mempelajari perekayasaan penyediaan jasa berupa informasi keuangan kuantitatif suatu unit organisasi dan cara penyampaian (pelaporan) informasi tersebut kepada pihak yang berkepentingan untuk dijadi-kan dasar dalam pengambilan keputusan ekonomi. Sedangkan akuntansi sebagai proses dapat didefinisikan sebagai proses pengidentifikasian, pengukuran, pencatatan, pengklasifikasian, penguraian, penggabungan, pe-ringkasan dan penyajian data keuangan dasar yang terjadi dari kejadian-kejadian, transaksitransaksi atau kegiatan operasi suatu unit or-ganisasi dengan cara tertentu untuk mengha-silkan informasi yang relevan bagi pihak yang berkepentingan.

Tingkat pemahaman akuntansi merupakan "Seberapa mengerti seorang mahasiswa terhadap apa yang sudah dipelajari yang dalam konteks ini mengacu pada mata kuliah-mata kuliah akuntansi". Tanda seorang mahasiswa memahami akuntansi tidak hanya ditunjukkan dari nilai-nilai yang di dapatkannya dalam mata kuliah, tetapi juga apabila mahasiswa tersebut mengerti dan dapat menguasai konsep-konsep yang terkait. Mahasiswa dapat dikatakan menguasai atau memahami akuntansi apabila ilmu akuntansi yang sudah di perolehnya selama ini dapat diterapkan dalam kehidupannya bermasyarakat atau dengan kata lain dapat dipraktekkan didunia kerja. Pendidikan akuntansi setidaknya harus dapat mempersiapkan peserta didik untuk memulai dan 
mengembangkan keaneragaman karir profesional dalam bidang Akuntansi.

Kecerdasan emosional yang baik terhadap pemahaman akuntansi dapat dilihat dari kemampuan mengenal dirisendiri, mengendalikan diri, memotivasi diri, berempati, dan kemampuan sosial. Olehkarena itu, mahasiswa yang memiliki ketrampilan emosi yang baik akan berhasil di dalam kehidupan dan memiliki motivasi untuk terus belajar. Sedangkan, mahasiswa yang memiliki ketrampilan emosi yang kurang baik, akan kurang memiliki motivasi untuk belajar, sehingga dapat merusak kemampuannya untuk memusatkan perhatian pada tugas-tugas individu tersebut sebagai mahasiswa.

Tingkat pemahaman akuntansi mahasiswa juga dipengaruhi oleh faktor Kecerdasan intelektual (IQ). Kecerdasan atau inteligensi merupakan kapasitas berpikir seseorang yang kemudian menentukan cara berpikir seseorang tersebut. Adanya suatu perbedaan kecepatan dan kesempurnaan seseorang dalam memecahkan masalah berbagai persoalan yang dihadapi. Inteligensi pada setiap orang berbeda-beda terhadap pemahaman belajar. Kecerdasan Intelektual (IQ) merupakan interprestasi hasil tes intelegensi (kecerdasan) kedalam angka yang dapat menjadi petunjuk mengenai kedudukan tingkat intelegensi seseorang. Kecerdasan Intelektual ini diukur dari nilai rapor dan indeks prestasi. Nilai rapor yang baik, indeks prestasi yang tinggi atau sering juara kelas merupakan tolak ukur dari kesuksesan seseorang.

Dalam tingkat pemahaman akuntansi diperlukan juga perilaku belajar yang sesuai dengan tujuan pendidikan, dimana dengan perilaku belajar tersebut tujuan pendidikan dapat dicapai secara efektif dan efisien, sehingga prestasi akademik dapat ditingkatkan. Perilaku belajar sering juga disebut kebiasaan belajar yaitu merupakan proses belajar yang dilakukan individu secara berulangulang sehingga menjadi otomatis atau spontan.

\section{METODE}

Objek pada penelitian ini adalah kecerdasan emosional, kecerdasan spiritual dan perilaku belajar terhadap pemahaman akuntansi. Populasi dalam penelitian ini adalah Mahasiswa Jurusan Akuntansi angkatan 2012-2013 di Universitas Lancang Kuning yang diabil secara menyeluruh baik reguler maupun non reguler.

Metode penetapan sampel yang digunakan adalah metode sensus, yaitu teknik pemilihan sampel bila semua anggota populasi digunakan sebagai sampel. (Sugiyono, 2008;122). Jenis data pada penelitian ini adalah data kualitatif, pengukuran variabel-variabel menggunakan instrument berbentuk pertanyaan, serta diukur menggunakan skala likert dari $1 \mathrm{~s} / \mathrm{d}$ 5. Sumber data yang digunakan adalah data primer, merupakan sumber data penelitian yang langsung diperoleh dari sumber asli atau tidak melalui perantara dan secara khusus dikumpulkan peneliti melalui pertanyaan kuesioner.

Data dikumpulakan melalui metode angket, yaitu menyebarkan daftar pertanyaan (kuesioner) yang akan diisi atau dijawab oleh responden Mahasiswa jurusan akuntansi universitas lancang kuning. Responden memberikan pendapat setiap butir pertanyaan mulai dari sangat tidak setuju sampai sangat setuju. Tahap-tahap dalam menganalisis data adalah melakukan pilot test untuk menguji kualitas data, setelah memperoleh data dari responden asli lalu membuat tabulasi profil dan jawaban responden, uji asumsi klasik dan pengujian hipotesis dengan menggunakan analisis regresi berganda untuk melihat hasil prediksi dan pengaruh dari masingmasing variabel terhadap pemahaman akuntansi.

\section{HASIL}

Adapun proses pengumpulan data yang telah dilakukan dari seluruh kuesioner yang telah disebarkan kepada Mahasiswa Jurusan Akuntansi di Universitas Lancang Kuning . Bab ini menguraikan data yang 
telah diperoleh, hasil pengolahan data serta analisis pembahasan pada variabel penelitian yang terdiri dari Variabel independen yaitu Pemahaman Akuntansi. Variabel dependen yaitu Pengaruh Kecerdasan Emosional, Kecerdasan Spiritual dan Perilaku Belajar. Pengukuran statistik sampel dalam penelitian ini dilakukan dengan menggunakan program komputer Statisical Product and Serice Solution (SPSS) Versi. 20 untuk mengetahui signifikansi setiap perbedaan nilai rata masing-masing variabel.

Tabel 1: Coeficient

\begin{tabular}{|c|c|c|c|c|c|}
\hline \multirow[b]{2}{*}{ Model } & \multicolumn{2}{|c|}{$\begin{array}{l}\text { Unstandardized } \\
\text { Coefficients }\end{array}$} & \multirow{2}{*}{\begin{tabular}{|l}
$\begin{array}{l}\text { Standardized } \\
\text { Coefficients }\end{array}$ \\
Beta
\end{tabular}} & \multirow[b]{2}{*}{$\mathrm{T}$} & \\
\hline & B & $\begin{array}{l}\text { Std. } \\
\text { Error }\end{array}$ & & & \\
\hline (Constant) & 24.150 & 1.950 & & 12.388 & 3.000 \\
\hline 1 KecerdasanEmosional & .253 & .082 & .217 & 3.083 & .002 \\
\hline Kecerdasan Spiritual & .394 & .103 & .259 & 3.818 & .000 \\
\hline PerilakuBelajar & .215 & .029 & .413 & 7.440 & .000 \\
\hline
\end{tabular}

a. Dependent Variable: PemahamanAkuntansi

Sumber: Data Olahan

Tabel 2: Uji F

\begin{tabular}{|l|ll|l|l|l|l|}
\hline Model & $\begin{array}{l}\text { Sum } \\
\text { Squares }\end{array}$ & of & Df & Mean Square & F & Sig. \\
\hline Regression & 3201.381 & 3 & 1067.127 & 128.786 & $.000^{\mathrm{b}}$ \\
1 & $\begin{array}{l}\text { Residual } \\
1889.223\end{array}$ & 228 & 8.286 & & \\
& & & & & \\
\hline
\end{tabular}

a. Dependent Variable: PemahamanAkuntansi

b.Predictors: (Constant), PerilakuBelajar, Kecerdasan Spiritual, KecerdasanEmosional

Sumber: Data Olahan

Pada pengujian secara simultan (Uji F) diperoleh $F_{\text {hitung }}$ sebesar 128.786 dengan signifikansi sebesar 0,000. Diperoleh $F_{\text {tabel }}$ sebesar 2,644. Dengan demikian dapat diketahui bahwa $\mathrm{F}_{\text {hitung }}>\mathrm{F}_{\text {tabel }}$ dengan sig. $(0,000<0,05)$, artinya variabel kecerdasan emosional, kecerdasan spiritual dan perilaku belajar secara bersama-sama berpengaruh signifikan terhadap variabel pemahaman akuntansi.

Bahwa besarnya nilai $\mathrm{R}$ diperoleh 0,793 sehingga diketahui nilai Koefesien Determinasi Simultan $\left(\mathrm{R}^{2}\right)$ sebesar 0,624 hal ini dapat diartikan bahwa variabel kecerdasan emosional $\left(\mathrm{X}_{1}\right)$, kecerdasan spiritual $\left(\mathrm{X}_{2}\right)$, dan perilaku belajar $\left(\mathrm{X}_{3}\right)$, mampu menjelaskan sebesar $62,4 \%$ terhadap pemahaman akuntansi(Y). Sedangkan sisanya $37,6 \%$ dijelaskan faktor lain yang tidak dimasukkan dalam penelitian ini. yang tidak dimasukkan dalam penelitian ini.

\section{PEMBAHASAN}

\section{Pengaruh kecerdasan emosional terhadap pemahaman akuntansi}

Pengujian pada $\mathrm{H}_{1}$ dilakukan untuk menguji pengaruh kecerdasan emosional terhadap pemahaman akuntansi. Hasil penelitian menunjukkan bahwa kecerdasan emosional berpengaruh signifikan terhadap pemahaman akuntansi.

Hasil penelitian ini mendukung hasil penelitian sebelumnya Trisniwati dan Suryaningsum (2003) dalam Prenichawati ishak (2010) yang mendefinisikan bawa "Kecerdasan emosional adalah kemampuan merasakan, memahami, dan secara selektif menerapkan daya dan kepekaan emosi sebagai sumber energi dan pengaruh yang manusiawi".

\section{Pengaruh kecerdasan spiritual terhadap pemahaman akuntansi}

Pengujian pada $\mathrm{H}_{2}$ dilakukan untuk menguji pengaruh kecerdasan spiritual terhadap pemahaman akuntansi. Hasil penelitian menunjukkan bahwa kecerdasan spiritual berpengaruh signifikan terhadap pemahaman akuntansi.

Hasil penelitian ini mendukung hasil penelitian sebelumnya Zohar dan Marshall (2007), kecerdasan spiritual adalah kecerdasan untuk menghadapi dan memecahkan persoalan makna dan nilai, yaitu kecerdasan untuk menempatkan perilaku dan hidup manusia dalam konteks makna yang lebih luas dan kaya, untuk menilai bahwa tindakan atau jalan hidup seseorang lebih bermakna dibandingkan yang lain. 


\section{Pengaruh perilaku belajar terhadap pemahaman akuntansi}

Pengujian pada $\mathrm{H}_{3}$ dilakukan untuk menguji pengaruh perilaku belajar terhadap pemahaman akuntansi. Hasil penelitian menunjukkan bahwa pemahaman akuntansi berpengaruh signifikan terhadap pemahaman akuntansi.

Hasil penelitian ini mendukung hasil penelitian sebelumnya yang dilakukan oleh Suwardjono (2004) menyatakan bahwa belajar di perguruan tinggi merupakan suatu pilihan srategik dalam mencapai tujuan individual seseorang. Semangat, cara belajar, dan sikap mahasiswa terhadap belajar sangat dipengaruhi oleh kesadaran akan adanya tujuan individual dan tujuan lembaga pendidikan yang jelas. Kuliah merupakan ajang untuk mengkonfirmasi pemahaman mahasiswa dalam proses belajar mandiri. Pengendalian proses belajar lebih penting daripada hasil atau nilai ujian. Jika proses belajar dijalankan dengan baik, nilai merupakan konsekuensi logis dari proses tersebut.

\section{Pengaruh kecerdasan emosional, kecerdasan spiritual dan perilaku belajar terhadap pemahaman akuntansi}

Pengujian pada $\mathrm{H}_{4}$ dilakukan untuk menguji pengaruh kecerdasan emosional, kecerdasan spiritual, perilaku belajar terhadap pemahaman akuntansi. Hasil penelitian menunjukkan bahwa kecerdasan emosional, kecerdasan spiritual, perilaku belajar secara bersama-sama berpengaruh signifikan terhadap pemahaman akuntansi.

Hasil penelitian ini mendukung hasil penelitian sebelumnya yang dilakukan oleh prenichawati ishak (2010), kurangnya kecerdasan spiritual dalam diri seorang mahasiswa akan mengakibatkan mahasiswa kurang termotivasi untuk belajar dan sulit untuk berkonsentrasi, sehingga mahasiswa akan sulit untuk memahami suatu mata kuliah. Sementara itu, mereka yang hanya mengejar prestasi berupa nilai atau angka dan mengabaikan nilai spiritual, akan menghalalkan segala cara untuk mendapakan nilai yang bagus, mereka cenderung untuk bersikap tidak jujur seperti mencontek pada saat ujian. Oleh karena itu, kecerdasan spiritual mampu mendorong mahasiswa mencapai keberhasilan dalam belajarnya karena kecerdasan spritual merupakan dasar untuk mendorong berfungsinya secara efektif kecerdasan emosional (EQ) dan akan berdampak pada proses pemahaman akuintansi yang baik.

Peran dosen juga besar dalam membangun kesadaran dari peserta didik dalam belajar, sebagaimana dijelaskan oleh Rahman, F., \& Suroto, b. (2018) bahwa sebagai dosen perlu meningkatkan berbagai metode pembelajaran guna meningkatkan kemampuan peserta didik.

\section{SIMPULAN}

Kecerdasan emosional berpengaruh signifikan terhadap pemahaman akuntansi. Karena kecerdasan emosional adalah kemampuan merasakan, memahami, dan secara selektif menerapkan daya dan kepekaan emosi sebagai sumber energi dan pengaruh yang manusiawi". Kecerdasan spiritual berpengaruh signifikan terhadap pemahaman akuntansi. Karena kecerdasan spiritual adalah kecerdasan untuk menghadapi dan memecahkan persoalan makna dan nilai, yaitu kecerdasan untuk menempatkan perilaku dan hidup manusia dalam konteks makna yang lebih luas dan kaya, untuk menilai bahwa tindakan atau jalan hidup seseorang lebih bermakna dibandingkan yang lain.

Perilaku belajar berpengaruh signifikan terhadap pemahamn akuntansi . Karena perilak belajar adalah kebiasaan, kemauan dan keterampilan belajar yang dimiliki seseorang. Pengendalian proses belajar lebih penting daripada hasil atau nilai ujian. Jika proses belajar dijalankan dengan baik, nilai merupakan konsekuensi logis dari proses tersebut. Kecerdasan emosional, kecerdasan spiritual dan perilaku belajar berpengaruh secara simultan dan signifikan terhadap pemahaman akuntansi. Karena jika mahasiswa memiliki pemahaman tentang kecerdasan emosional, kecerdasan spiritual 
dan perilaku belajar ada dalam dirinya maka berdampak pada proses pemahaman akuntansi yang baik.

\section{DAFTAR RUJUKAN}

Agustian, Ary Ginanjar. 2004.Rahasia Sukses Membangun Kecerdasan Emosi dan Spiritual ESQ, Arga, Jakarta.

Ahmad Rizal Jayadi. 2011, Pengaruh kecerdasan emosional dan minat belajar terhadap pemahaman akuntansi. Universitas Brawijaya.

Amsi Amalia Lutfi. 2007. Pengaruh Kecerdasan Emosional dan Kecerdasan Spiritual Terhadap Tingkat Pemahaman Akuntansi. Universitas Islam Sultan Agung.

Armansyah, 2002, Intelegency Quotient, Emotional Quotient, dan Spiritual Quotient dalam Membentuk Prilaku Kerja. Jurnal Manajemen dan Bisnis. 02, (01), 23-32

Budhiyanto, Suryanti Juni dan Paskah, Ika Nugroho, , 2004, Pengaruh Kecerdasan Emosional terhadap Tingkat Pemahaman Akuntansi", Jurnal EkonomiBisnis, Vol. X, No.2, Hal.260-281

Filia Rachmi, 2010 Pengaruh Kecerdasan Emosional, Kecerdasan Spiritual, Dan Perilaku Belajar Terhadap Tingkat Pemahaman Akuntansi.

Ghozali, 2011. Aplikasi Analisis Multivariate dengan Program IBM SPSS 21. Edisi Ketujuh, BP, Universitas Diponerogo.

Goleman, Daniel. 2005.Emotional Intelligence. Jakarta: PT. Gramedia Pustaka Utama.
Masyitah as sahara. 2014. Pengaruh perilaku belajar, kecerdasan emosional, kecerdasan intelektual, kecerdasan spiritual, dan kecerdasan sosial terhadap pemahaman akuntansi. Universitas maritim raja ali haji, tanjungpinang

Melandy, Risso dan Aziza, Nurna. 2006. Pengaruh Kecerdasan Emosional ter- hadap Tingkat Pemahaman Akuntansi, Kepercayaan Diri sebagai Variabel Pemoderasi. Makalah SNA IX. Padang 23-26 Agustus 2006. Napitupulu

Mu'tadin, Zainun. 2010. Mengenal Kecerdasan Emosional Remaja. http://www.e-psikologi.com.

Rahman, F., \& Suroto, B. (2018). Model Pengembangan Kinerja Dosen Swasta (Studi pada Karyawan yang berprofesi sebagai Dosen). Human Sustainability Procedia.

Septian Hariyoga Edy Suprianto (2011), Pengaruh Kecerdasan Emosional, Perilaku Belajar, Dan Budaya Terhadap Tingkat Pemahaman Akuntansi Dengan Kepercayaan Diri Sebagai Variabel Pemoderasi 